\title{
Ovarian signalling pathways regulated by leptin during the ovulatory process
}

\author{
María Paula Di Yorio, María Guillermina Bilbao, Ana María Biagini-Majorel and \\ Alicia Graciela Faletti \\ Centro de Estudios Farmacológicos y Botánicos (CEFYBO), Consejo Nacional de Investigaciones Científicas y \\ Técnicas (CONICET), Facultad de Medicina, Universidad de Buenos Aires, Paraguay 2155, $16^{\circ} \mathrm{P}$, \\ C1121ABG Buenos Aires, Argentina \\ Correspondence should be addressed to A G Faletti; Email: agfaletti@yahoo.com.ar
}

\begin{abstract}
Leptin, a protein secreted by different tissues, is able to exert both stimulatory and inhibitory effects on the ovulatory process. Thus, we investigated whether these opposite effects involve changes in the ovarian signalling pathways in response to different levels of leptin. To this end, we performed both in vivo and in vitro assays using immature rats primed with gonadotrophins to induce ovulation. The acute treatment with leptin, which inhibits the ovulatory process, caused a significant decrease in the phosphorylation of both STAT3 and ERK1/2 and a simultaneous increase in suppressors of cytokine signalling 3 (SOCS3) protein. However, daily administration of a low dose of leptin, which induces the ovulatory process, showed increased phosphorylation of both STAT3 and ERK1/2 and a decreased expression of SOCS3 protein. Using ovarian explant cultures, we also found that leptin was able to activate both STAT3 and ERK1/2 at $10 \mathrm{ng} / \mathrm{ml}$ but only STAT3 at 300-500 $\mathrm{ng} / \mathrm{ml}$. In addition, at 100-300 $\mathrm{ng} / \mathrm{ml}$, leptin increased protein but not mRNA expression of SOCS3. The addition of specific inhibitors of JAK/STAT and MAPK signalling pathways suppressed both the increase and the decrease in leptin-induced progesterone secretion. These results indicate that i) different levels of leptin are able to regulate STAT3, ERK1/2 and SOCS3 at both intra- and extra-ovarian level and that ii) the dual action of leptin on steroidogenesis seems to occur, at least in part, through both the ERK and STAT cascades.
\end{abstract}

Reproduction (2013) $\mathbf{1 4 6} 647-658$

\section{Introduction}

Leptin, the obese $(\mathrm{OB})$ gene product, is synthesised and secreted by different types of cells, including adipocytes, and transported via blood to act as a multifunctional hormone in all tissues. It is involved in different physiological processes both in the CNS and in the periphery, including the reproductive system. Leptin acts through its transmembrane receptors, which have been localised mainly in different neuronal populations of the hypothalamus and many peripheral organs, including the reproductive system (Cioffi et al. 1996, 1997, Karlsson et al. 1997, Nakamura et al. 2009). Only the long isoform (OBRb) was initially considered to be a functional receptor because it contains all the intracellular domains required for effective signalling through activation of both the JAK/STAT and MAPK pathways (Tartaglia et al. 1995, Bjørbæk et al. 1997). However, OBRa, one of the short isoforms, also has different signalling capacities, especially through the MAPK pathway (Bjørbæk et al. 1997, Murakami et al. 1997, Caüzac et al. 2003, Ye et al. 2009). As OBRb does not have intrinsic enzymatic activity, its signalling cascade occurs via JAK2, which undergoes autophosphorylation and simultaneously induces phosphorylation in other tyrosine residues in the cytoplasmic region of the leptin receptor, which, in turn, allows the association of STAT proteins. Then, these proteins are phosphorylated, dissociated from the receptor, and dimerised to translocate to the nucleus to regulate gene transcription. The signalling cascade via JAK/STAT activation is mainly regulated by suppressors of cytokine signalling (SOCS) proteins (Bjørbæk et al. 1998, Baskin et al. 2000). The SOCS family consists of eight structurally homologous proteins whose expression is induced by exposure to several cytokines and other growth factors. It has been reported that leptin is able to induce the expression of SOCS3 in both the hypothalamus and Chinese hamster ovary $(\mathrm{CHO})$ cells, but not that of SOCS1 or SOCS2. SOCS3 also regulates the signal transduction modulated by leptin (Bjørbæk et al. 2000, Laubner et al. 2005, Eguchi et al. 2007) and has been proposed as a potential mediator of leptin resistance (Bjørbæk et al. 1998, 1999). In addition to JAK/STAT, other signalling factors can be activated by leptin receptors. Some studies have shown that leptin can stimulate the activity 
of MAPK by either the long or the short isoform, although some authors state that the latter does so to a lesser extent (Bjørbæk et al. 1997, 2001, Banks et al. 2000). Activation of the MAPK signalling pathway phosphorylates ERK proteins that induce the gene transcription of the specific gene target (Bjørbæk et al. 1997, Kim et al. 2000).

Administration of leptin to $o b / o b$ mice, which lack circulating leptin, causes decreased food intake, body weight loss, increased ovarian weight, increased number of follicles and restoration of fertility (Chehab et al. 1996, Cioffi et al. 1997, Mounzih et al. 1997). Leptin has both inhibitory and stimulatory actions on ovarian function. Regarding its inhibitory actions, i) leptin can directly suppress insulin, insulin-like growth factor 1 (IGF1), transforming growth factor- $\beta$ and glucocorticoidinduced steroidogenesis of ovarian granulosa cells of rats (Zachow \& Magoffin 1997, Barkan et al. 1999, Zachow et al. 1999) or humans (Agarwal et al. 1999); ii) acute administration of leptin to immature gonadotrophin-primed rats inhibits ovulation (Duggal et al. 2000, 2002) and iii) leptin inhibits preantral follicles cultured in the presence of follicle-stimulating hormone (FSH; Kikuchi et al. 2001). Regarding its stimulatory actions, i) leptin accelerates the onset of puberty in rodents (Ahima et al. 1997, Almog et al. 2001) and humans (Clément et al. 1998, Strobel et al. 1998); ii) leptin induces ovulation in gonadotrophin-releasing hormone-deficient mice (Barkan et al. 2005) and equine chorionic gonadotrophin (eCG)/human chorionic gonadotrophin (hCG)-primed rats (Roman et al. 2005) and iii) leptin enhances meiotic oocyte maturation and oocyte quality through the activation of both JAK2/STAT3 and MEK $1 / 2$ pathways in the rabbit oocyte model (Matsuoka et al. 1999, Craig et al. 2004, Arias-Álvarez et al. 2010). Previous in vivo studies have shown that an acute treatment with leptin inhibits ovulation (Duggal et al. 2000, Ricci et al. 2006) but that a daily treatment with a low dose enhances ovulation in comparison with control animals (Almog et al. 2001, Barkan et al. 2005, Roman et al. 2005) and partially prevents the negative effects caused by severe malnutrition (Gruaz et al. 1998, Roman et al. 2005). Therefore, in this study, we began to assess whether the dual and opposite effects of leptin on the ovulatory process involve changes in the signalling pathways in response to this protein at the ovarian level.

\section{Materials and methods}

\section{Animals}

Immature female Sprague Dawley rats aged 21 days were purchased from the School of Veterinarian Sciences of the Buenos Aires University, Argentina. All the animals were kept under controlled conditions of light (12 h light:12 h darkness), temperature $\left(22^{\circ} \mathrm{C}\right)$ and humidity, with free access to food and water. In all the experiments, prepubertal rats were i.p. injected with $15 \mathrm{IU}$ eCG (in $0.10 \mathrm{ml}$ saline) at $0800 \mathrm{~h}$ to induce the growth of the first generation of preovulatory follicles and to prevent the confounding effects of the presence of different types of follicles and corpora lutea from previous cycles. After $48 \mathrm{~h}$, the animals were i.p. injected with $15 \mathrm{IU}$ hCG (in $0.10 \mathrm{ml}$ saline) to induce ovulation, which, in this rat strain, usually occurs within $12 \mathrm{~h}$ after hCG administration. Animals were handled according to the Guiding Principles for the Care and Use of Research Animals, and all the protocols were approved by the Institutional Committee of the Medicine School of the Buenos Aires University (CICUAL) by Resolution 2079/07.

\section{In vivo studies}

Rats received one of the following treatments (Fig. 1): i) acute treatment (Ricci et al. 2006), which consisted of five i.p. injections of either recombinant rat leptin ( $5 \mu \mathrm{g} / 0.15 \mathrm{ml}$ PBS-BSA) or PBS-BSA alone (control) $1 \mathrm{~h}$ before hCG administration and at intervals of $150 \mathrm{~min}$ until killing and ii) daily treatment (Roman et al. 2005), at 22 days of age, which consisted of an i.p. injection of either recombinant rat leptin $(3 \mu \mathrm{g} / 0.15 \mathrm{ml}$ PBS-BSA) or PBS-BSA alone (control) per day until killing. After 10 days of treatment, these animals were injected with gonadotrophin as indicated before. In total, these rats received 12 injections of leptin.

Rats (eight to ten per group) were killed by decapitation $10 \mathrm{~h}$ after hCG administration in the acute treatment, and $5 \mathrm{~h}$ $(1300 \mathrm{~h})$ and $10 \mathrm{~h}(1800 \mathrm{~h})$ after hCG injection in the daily treatment. The timing samples were selected because i) many of the proinflammatory factors that are up-regulated in the ovary during the ovulatory process in response to hCG are at their maximum expressions in control animals and can be significantly modified by leptin (Roman et al. 2005, Ricci et al. 2006) and ii) $10 \mathrm{~h}$ after hCG administration in the acute treatment and $5 \mathrm{~h}$ after hCG in the daily treatment represent $1 \mathrm{~h}$ after the last leptin administration, a period that is necessary to obtain an adequate signalling response to leptin as demonstrated below. Both treatments attempt to simulate rats exposed to i) leptin levels that induce ovulation (daily treatment; Almog et al. 2001, Roman et al. 2005) and ii) high levels of leptin (acute treatment), as it occurs in obese rats, that inhibit ovulation (Duggal et al. 2000, Ricci et al. 2006). In all cases, both ovaries were immediately dissected out, frozen on dry ice and stored at $-72{ }^{\circ} \mathrm{C}$ until use. Only one ovary from each animal was used in these studies.

\section{In vitro studies}

\section{Ovarian explant culture}

Animals were killed by decapitation $4 \mathrm{~h}$ after hCG administration and the ovarian tissues were incubated as described previously (Ricci et al. 2006). Briefly, the ovaries were removed and dissected free of fat and bursa and cut into pieces of approximately equal size. After 30-min preincubation, ovarian slices (four slices per ovary per well) were randomly distributed in DMEM/F12 (1:1) medium (Bio-Rad Laboratories) containing $25 \mathrm{mmol} / \mathrm{l}$ HEPES, $100 \mathrm{U} / \mathrm{ml}$ penicillin, $100 \mu \mathrm{g} / \mathrm{ml}$ streptomycin, $0.5 \mu \mathrm{g} / \mathrm{ml}$ fungizone, and $2 \mathrm{mmol} / \mathrm{l}$ L-glutamine. 

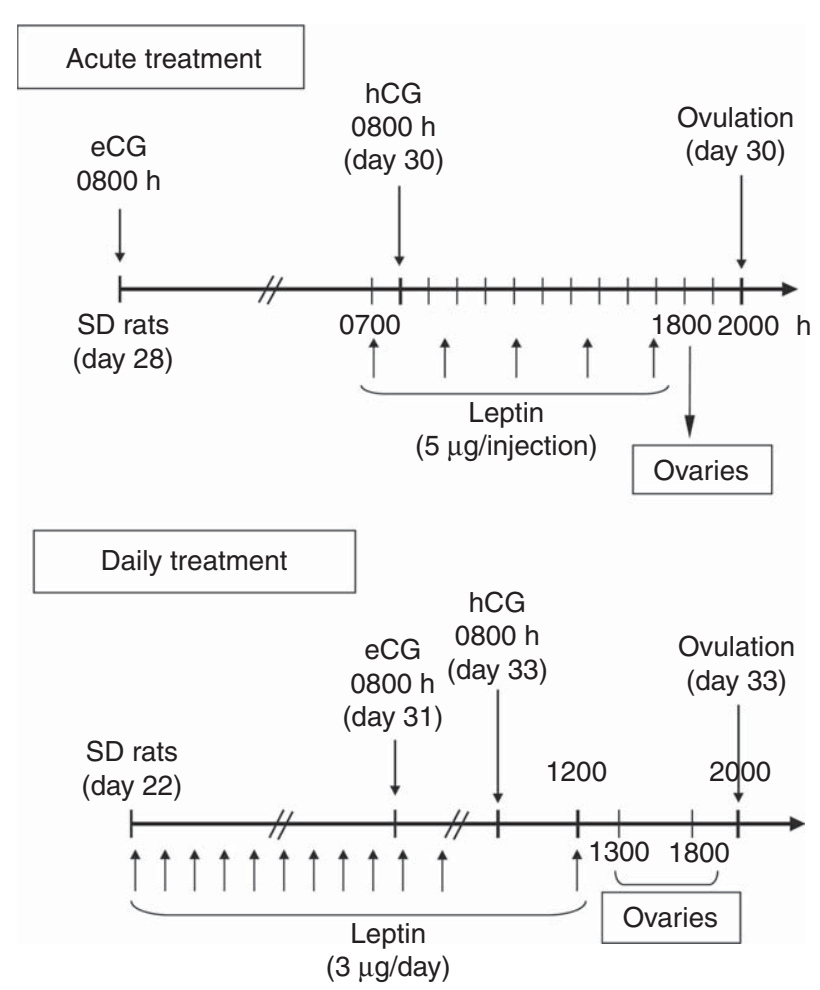

Figure 1 Schematic representation of the leptin treatments performed in our experiments. Acute treatment (upper panel): rats were injected with $15 \mathrm{IU}$ eCG at 28 days of age and $15 \mathrm{IU}$ hCG $48 \mathrm{~h}$ later. Both injections were administered at $0800 \mathrm{~h}$. Leptin was administered within before hCG administration and killed through five injections of recombinant rat leptin or vehicle at 150-min intervals (0700, 0930, 1200, 1430 and $1700 \mathrm{~h}$; up arrow). Rats were killed by decapitation at $10 \mathrm{~h}(1800 \mathrm{~h})$ after hCG administration. In this rat strain, ovulation occurs within $12 \mathrm{~h}$ after hCG administration. Daily treatment (bottom panel): at 22 days of age, rats were daily injected with $5 \mu \mathrm{g}$ leptin or vehicle at $1200 \mathrm{~h}$ until killed. In total, the animals received 12 injections. In addition, all rats received $15 \mathrm{IU}$ eCG at 31 days of age and $15 \mathrm{IU}$ hCG $48 \mathrm{~h}$ later. Both injections were administered at $0800 \mathrm{~h}$. Rats were killed by decapitation at $5 \mathrm{~h}(1300 \mathrm{~h})$ and $10 \mathrm{~h}(1800 \mathrm{~h})$ after hCG administration. In this rat strain, ovulation occurs within $12 \mathrm{~h}$ after hCG administration. SD, Sprague Dawley.

Ovarian slices were then incubated at $37{ }^{\circ} \mathrm{C}$ in a humidified atmosphere $\left(5 \% \mathrm{CO}_{2}: 95 \% \mathrm{O}_{2}\right)$ i) for 1 and $4 \mathrm{~h}$ in the presence or absence of different leptin concentrations $(0.3-500 \mathrm{ng} / \mathrm{ml})$ to study the signalling proteins STAT3, ERK1/2 and SOCS3 and ii) for $4 \mathrm{~h}$ in the presence or absence of a combination of different leptin concentrations (1-300 ng/ml), a specific MAPK inhibitor PD 98059 (50 $\mu \mathrm{mol} / \mathrm{l}$, Sigma-Aldrich) and a specific JAK2/STAT3 inhibitor AG 490 (25 $\mu \mathrm{mol} / \mathrm{l}$, SigmaAldrich) to study progesterone secretion. The range of leptin concentrations was based on previous studies (Duggal et al. 2000, 2002, Ricci et al. 2006), and in the latter case, we used only those able to alter progesterone secretion, as described previously (Di Yorio et al. 2008). After the incubation periods, ovarian tissues and the culture media were recovered and frozen on dry ice and stored at $-72{ }^{\circ} \mathrm{C}$ until use. Each experiment was repeated at least six times.

\section{RNA isolation and semiquantitative RT-PCR}

Total RNA was isolated from the frozen tissues using TRI Reagent (Molecular Research Centre, Cincinnati, OH, USA) according to the manufacturer's instructions. The organic phase of each sample was saved for protein extraction. Total RNA quantitation and purity determination was assessed by spectral absorption (A260/280) prior to RT-PCRs. cDNA was synthesised from $4 \mu \mathrm{g}$ RNA in $25 \mu \mathrm{l}$ reaction mixture containing $200 \mathrm{U}$ Moloney murine leukemia virus (Promega), oligonucleotides (Random Primers, Invitrogen) and dNTPs (Promega). CDNA was amplified by PCR in a total volume of $25 \mu \mathrm{l}$ using the primers and the cycles detailed in Table 1. Each reaction also contained $1 \mathrm{U}$ Taq-DNA polymerase (Invitrogen), $0.2 \mathrm{mmol} / \mathrm{l}$ of each primer (Invitrogen), $0.2 \mathrm{mmol} / \mathrm{l}$ of each $\mathrm{dNTP}$ and $1.5 \mathrm{mmol} / \mathrm{MgCl}_{2}$. The PCR profiles consisted of an initial denaturing step at $94{ }^{\circ} \mathrm{C}$ for $5 \mathrm{~min}$ and an appropriate number of denaturing cycles at $94{ }^{\circ} \mathrm{C}$ for $40 \mathrm{~s}$, annealing at $57{ }^{\circ} \mathrm{C}$ for $30 \mathrm{~s}$, extension at $72{ }^{\circ} \mathrm{C}$ for $1 \mathrm{~min}$ and a final extension step at $72{ }^{\circ} \mathrm{C}$ for $5 \mathrm{~min}$. The primer sequence used to amplify SOCS3 was that described previously (Peiser et al. 2000; Table 1). In preliminary experiments, the optimum cycle number was determined for each target, so that signals were always in the exponential portion of the amplification curve. An aliquot of each sample of the PCR was electrophoresed in $2 \%(\mathrm{w} / \mathrm{v})$ agarose gel with subsequent ethidium bromide $(10 \mathrm{mg} / \mathrm{ml})$ staining. mRNA bands were visualised and quantified using Image Quant RT ECL (General Electric, Amersham Bioscience Argentina SA) and the freely downloadable ImageJ Software respectively. Data were normalised to $\beta$-actin mRNA in each sample, the primer sequence of which was designed by Primer3 Software, as described previously (Rozen \& Skaletsky 2000). Negative controls were performed without reverse transcriptase or RNA.

\section{Protein isolation and western blot analysis}

Proteins were isolated from the organic phase of RNA isolation according to the manufacturer's instructions. Equal amounts of protein $(200 \mu \mathrm{g})$ were separated by SDS-PAGE $(10 \%$ for STAT3 and $15 \%$ for ERK $1 / 2$ and SOCS3). Proteins were transferred to PVDF membranes (Bio-Rad Laboratories) for $60 \mathrm{~min}$ in a cold chamber using a Bio-Rad transblot apparatus. Membranes were first blocked at $4{ }^{\circ} \mathrm{C}$ overnight in Tris- $\mathrm{HCl}$ :saline (50 mmol/l Tris-HCl:150 mmol// NaCl, pH 7.5) containing $5 \%(\mathrm{w} / \mathrm{v})$ non-fat milk powder and then incubated at $4{ }^{\circ} \mathrm{C}$ overnight with a specific primary antibody. Rabbit anti-STAT3 (C-20), anti-ERK1/2 (C-16) and anti-phosphorylated ERK1/2 (p-ERK1/2, Thr202/Tyr204) polyclonal antibodies (Santa Cruz Biotechnology), rabbit anti-actin polyclonal antibody (SigmaAldrich), goat anti-phosphorylated STAT3 (p-STAT3, Tyr705) and anti-SOCS3 (M-20) polyclonal antibodies (Santa Cruz Biotechnology), each diluted $1 / 200$, were used. Following washing, membranes were treated for $1 \mathrm{~h}$ at room temperature with goat anti-rabbit IgG for STAT3, ERK1/2, p-ERK1/2 and $\beta$-actin, and bovine anti-goat IgG for p-STAT3 and SOCS3, diluted $1 / 10000$ as the secondary antibody (Jackson ImmunoResearch Lab, Inc., West Grove, PA, USA). Immunoreactive bands were visualised using chemiluminescence detection 
Table 1 Primers used for PCR for detection of SOCS3 and actin in ovarian tissue from immature rats primed with eCG/hCG.

\begin{tabular}{|c|c|c|c|c|c|}
\hline Gene & Oligonucleotide sequences & $\begin{array}{c}\text { Annealing } \\
\text { temperature }\left({ }^{\circ} \mathrm{C}\right)\end{array}$ & Cycles & Product size $(b p)$ & GenBank \\
\hline SOCS3 & $\begin{array}{l}\text { Sense: 5'-CCTTTGAGGTTCAGGAGCAG-3' } \\
\text { Antisense: 5'-GGCTGGATTTTTGTGCTTGT-3' }\end{array}$ & 57 & 35 & 382 & NM053565 \\
\hline$\beta$-actin & $\begin{array}{l}\text { Sense: 5'-AGCCATGTACGTAGCCATCC-3' } \\
\text { Antisense: } 5^{\prime} \text {-CTCTCAGCTGTGGTGGTGAA-3' }\end{array}$ & 57 & 35 & 228 & NM031144.2 \\
\hline
\end{tabular}

reagents (Sigma-Aldrich) and Image Quant RT ECL (General Electric) and quantified by Imagej Software. Before reuse, membranes were stripped, blocked and reprobed according to the manufacturer's instructions. Negative controls were carried out by omitting the incubation with the primary antibody and no bands were detected. Molecular weight standards (Kaleidoscope St, Bio-Rad Laboratories) were run under the same conditions to identify protein bands. Phosphorylated proteins were expressed as the ratio of phosphorylated to total protein, and SOCS3 expression was normalised to $\beta$-actin protein levels in each sample to avoid procedural variability.

\section{Progesterone RIA}

Progesterone was quantified by RIA in the ovarian culture medium as described previously (Ricci et al. 2006). Antisera were kindly provided by $\mathrm{Dr}$ G D Niswender (Colorado State University, Fort Collins, CO, USA). The sensitivity was $7 \mathrm{pg} / \mathrm{ml}$ and the cross-reactivities were $12.0 \%$ for $20 \alpha$-dihydroprogesterone and $1.0 \%$ for other steroids. Results are expressed as nanograms per milligram protein. The intra- and interassay coefficients of variation were 7.0 and $8.5 \%$ respectively.

\section{Statistical analysis}

All data are expressed as means \pm s.E.M. Statistical analysis for in vivo experiments was performed by Student's $t$-test, whereas that for in vitro experiments was performed by i) one-way ANOVA with Dunnett's multiple comparison test for mRNA and protein determination and ii) two-way ANOVA with Bonferroni's post-test for progesterone secretion. Differences between groups were considered significant when $P<0.05$.

\section{Results \\ Preliminary assays}

To study the effect of leptin on the signalling pathways in the ovarian tissue, we first examined the timing and ability of leptin to induce the phosphorylation of STAT3 and ERK1/2 (Fig. 2). We found that leptin increased the phosphorylation of both STAT3 (Fig. 2A) and ERK1/2 (Fig. 2B), with maxima at $60 \mathrm{~min}$. Reduced or no phosphorylation was detected at longer times (data not shown). Thus, the expressions of both phosphorylated and total STAT3 and ERK $1 / 2$ proteins were assessed after i) 60 min of the last leptin administration in the in vivo assays and ii) a 60-min incubation in the presence of different leptin concentrations in the in vitro assays. As leptin mRNA has been found in ovarian cells of many species (Cioffi et al. 1997, Ryan et al. 2003), this endogenous protein or some other factors like interleukins, hormones or other cytokines can stimulate phosphorylation of these proteins. Therefore, the phosphorylation detected in the control samples may be either a leptin-independent and/or a leptin-dependent activation.

\section{In vivo studies}

To study whether the dual and opposite in vivo effects of leptin on the ovulatory process involves changes in the transduction signal pathways, rats received either the acute or daily treatment with leptin described in the Materials and methods section, and the phosphorylation of different signalling proteins was analysed in the ovarian tissue. In the acute treatment, phosphorylation of STAT3, expressed as the ratio of phosphorylated to total protein, was significantly lower than that in control animals ( $-30 \%, P<0.05$; Fig. 3A, left graphic).

Because leptin has been shown to activate other signalling pathways as MAPK in a variety of biological systems, especially in cells that have the short isoform of the leptin receptor (Murakami et al. 1997, Banks et al. 2000, Bjørbæk et al. 2001), we assessed phosphorylation of ERK $1 / 2$ by this acute
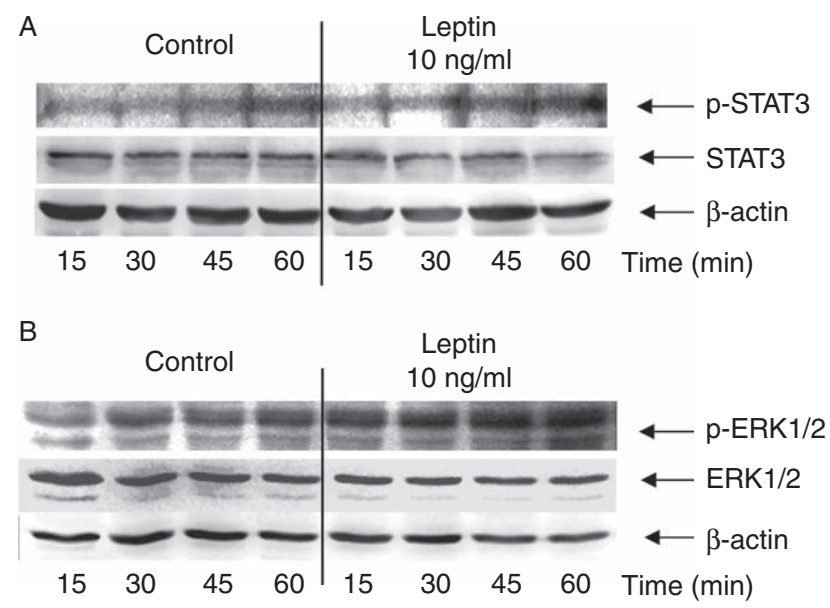

Figure 2 Time course for the in vitro phosphorylation of STAT3 (A) and ERK1/2 (B) in ovarian tissue obtained $4 \mathrm{~h}$ after hCG administration from immature rats primed with eCG/hCG and incubated for 15, 30, 45 and $60 \mathrm{~min}$ in the presence or absence of leptin $(10 \mathrm{ng} / \mathrm{ml})$, as described in the Materials and methods section. Phosphorylated proteins were detected by western blot analysis. 
A

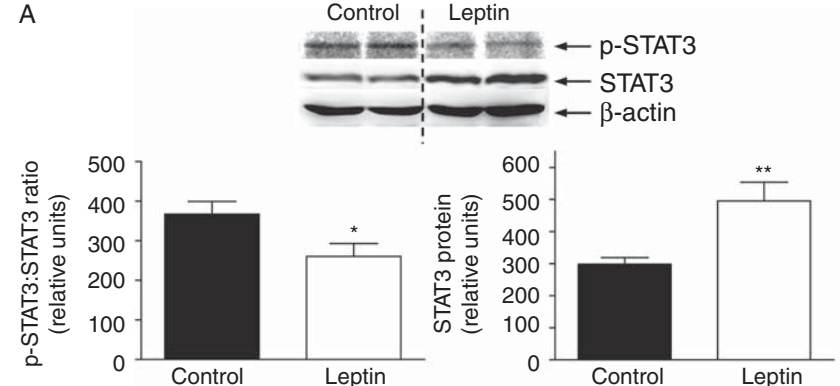

B
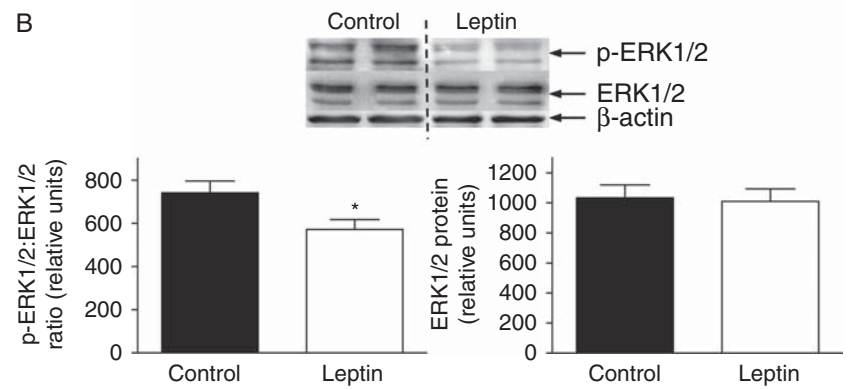

Figure 3 In vivo effect of the acute treatment with leptin on the ovarian expression of STAT3 and ERK1/2. Immature rats were primed with eCG/hCG and treated with vehicle (control) or $5 \mu \mathrm{g}$ leptin at $1 \mathrm{~h}$ before hCG and at 150-min intervals. Animals were killed $10 \mathrm{~h}$ after hCG administration, which represents $1 \mathrm{~h}$ after the last injection of leptin. (A and B) Representative blots (upper panel) showing the ovarian expression of phosphorylated and total STAT3 (A) and ERK1/2 (B) protein and quantitative analysis (bottom panel) of these proteins expressed as the ratio of phosphorylated to total protein (left graphics) and the total proteins normalised relative to $\beta$-actin (right graphics). Data points represent the mean \pm S.E.M. for eight to ten samples per group. Each sample represents one ovary from each animal with the same treatment $(n=8-10) .{ }^{*} P<0.05$ and ${ }^{*} * P<0.01$ vs controls (Student's $t$-test).

treatment. Phosphorylation of ERK1/2 was slightly but significantly lower than that in control animals $(-24 \%$, $P<0.05$; Fig. 3B, left graphic). After the acute treatment with leptin, the expression of total ERK1/2 protein was not changed (Fig. 3B, right graphic), whereas that of total STAT3 protein was significantly increased $(56 \%$, $P<0.01)$ when compared with control animals (Fig. 3A, right graphic).

In the daily treatment with leptin, when ovarian tissues were obtained $1 \mathrm{~h}$ after the last injection of leptin (5 h after hCG), we found increased phosphorylation of both STAT3 $(+25 \%, P<0.05)$ and ERK $1 / 2(+44 \%$, $P<0.01)$ when compared with those obtained in control animals (Fig. 4A and $B$ respectively), but no differences in the expression of total proteins (data not shown). On the other hand, when ovarian tissues were obtained $6 \mathrm{~h}$ after the last injection of leptin ( $10 \mathrm{~h}$ after hCG), we found no differences in the phosphorylated and total signalling proteins between leptin-treated and control animals (data not shown).

The levels of expression of both mRNA and protein of SOCS3 were evaluated in the same samples as the other signalling proteins. In rats that received the acute treatment, the relative expression of SOCS3 protein was significantly higher than in control animals $(42 \%$, $P<0.05)$, whereas that of mRNA was similar in both groups (Fig. 5). In rats that received the daily treatment, the mRNA and protein expression of SOCS3 in the ovaries obtained $1 \mathrm{~h}$ after the last administration of leptin (5 h after hCG) was similar to that in control animals (data not shown). However, in the ovaries obtained $10 \mathrm{~h}$ after hCG administration, the expression of SOCS3 protein $(45 \%, P<0.05)$, but not of SOCS3 mRNA, was significantly lower than that in control animals (Fig. 6).
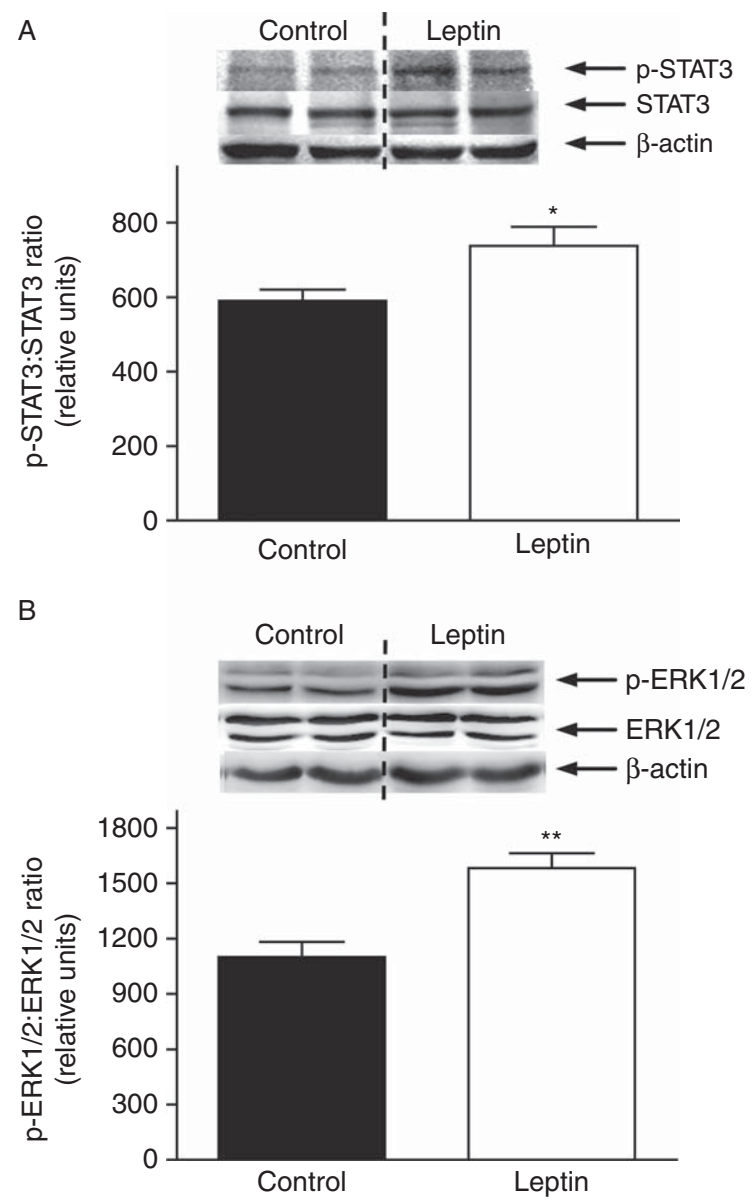

Figure 4 In vivo effect of the daily treatment with leptin $(3 \mu \mathrm{g} /$ day) on the ovarian expression of STAT3 and ERK $1 / 2$ in immature rats. On day 22 of age, rats received injections of either vehicle (control) or $3 \mu \mathrm{g}$ leptin/day. After 10 days of treatment, animals received the eCG/hCG stimulation as indicated in the Materials and methods section. Animals were killed $5 \mathrm{~h}$ after hCG administration, which represents $1 \mathrm{~h}$ after the last injection of leptin. (A and B) Representative blots (upper panel) showing the ovarian expression of both phosphorylated and total STAT3 (A) and ERK1/2 (B) and quantitative analysis (bottom panel) of these proteins expressed as the ratio of phosphorylated to total protein. Data points represent the mean \pm s.E.M. for eight to ten samples per group. Each sample represents one ovary from each animal with the same treatment $(n=8-10) .{ }^{*} P<0.05$ and $* * P<0.01$ vs controls (Student's $t$-test). 
A
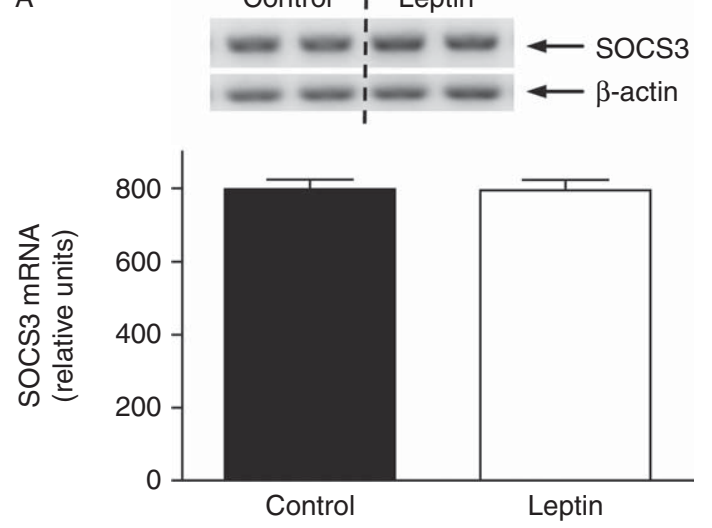

B

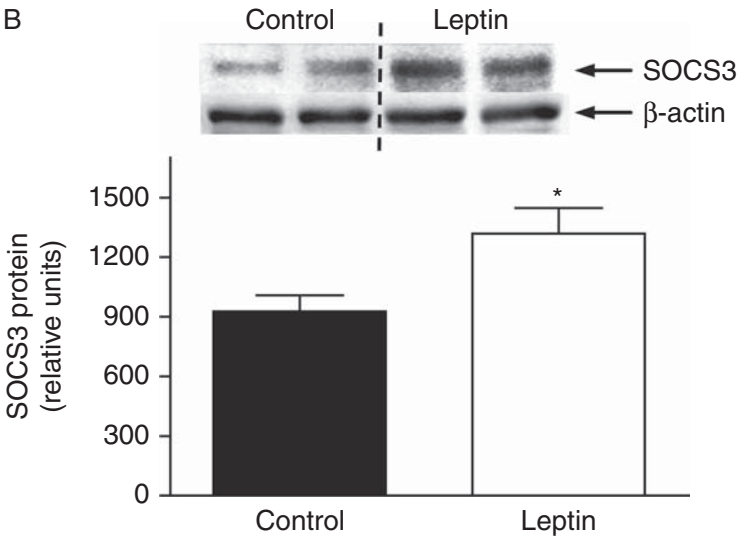

Figure 5 In vivo effect of the acute treatment with leptin on the ovarian expression of both SOCS3 mRNA and protein. Immature rats were primed with eCG/hCG and treated with vehicle (control) or $5 \mu \mathrm{g}$ leptin at $1 \mathrm{~h}$ before hCG and 150-min intervals. Animals were killed $10 \mathrm{~h}$ after hCG administration, which represents $1 \mathrm{~h}$ after the last injection of leptin. (A) Ovarian mRNA expression of SOCS3 and $\beta$-actin as transcript control, by RT-PCR (upper panel) and quantitative analysis of mRNA bands (bottom panel). (B) Ovarian expression of SOCS3 protein and $\beta$-actin, as protein control, by western blot assay (upper panel) and quantitative analysis of immunoreactive bands (bottom panel). Results are expressed as the mean \pm s.E.M. for eight to ten samples per group. Each sample represents one ovary from each animal with the same treatment $(n=8-10) .{ }^{*} P<0.05$ vs controls (Student's $t$-test).

\section{In vitro studies}

To study the effect of a narrow range of leptin concentrations on STAT3, ERK $1 / 2$ and SOCS3 and to investigate whether the ovary is involved in the changes found in the in vivo studies, these signalling proteins were measured in ovarian explant cultures. When the ovarian explants were incubated for $1 \mathrm{~h}$, the presence of leptin caused significant increases in the expression of phosphorylated proteins at different ranges of leptin levels: at 10,300 and $500 \mathrm{ng} / \mathrm{ml}$ for p-STAT3 and at 3-10 ng/ml for p-ERK1/2 (Fig. 7A and B respectively). These increases ranged between 32 and $63 \%(P<0.05)$, when compared with controls. The expression of total ERK $1 / 2$ protein after incubation for $1 \mathrm{~h}$ was not changed (Fig. 7B, right graphic), whereas that of total STAT3 protein was significantly increased when the ovarian tissue was exposed to the highest concentrations of leptin (Fig. 7A, right graphic). These increases ranged between 58 and $87 \%$ when compared with controls. No phosphorylation of STAT3 or ERK1/2 was detected after incubation for $4 \mathrm{~h}$ in the presence of leptin (data not shown). No difference was found in the expression of SOCS3 mRNA and protein after $1 \mathrm{~h}$ incubation in the presence of leptin when compared with controls (data not shown). However, when the ovaries were incubated for $4 \mathrm{~h}$, the expression of SOCS3 protein (Fig. 8B), but not of SOCS3 mRNA (Fig. 8A), was significantly increased at high concentrations of leptin.

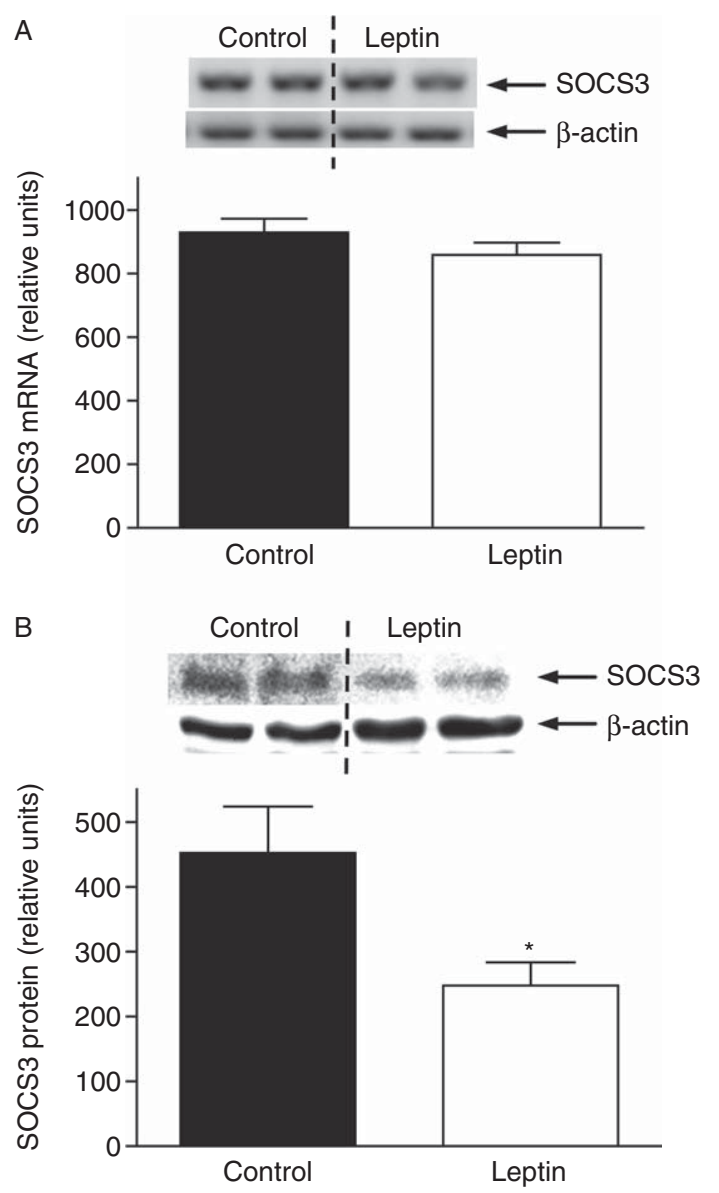

Figure 6 In vivo effect of the daily treatment with leptin on the ovarian expression of both SOCS3 mRNA and protein. Immature rats were daily treated with vehicle (control) or $3 \mu \mathrm{g}$ leptin starting at 22 days of age. After 10 days of treatment, animals were primed with eCG/hCG as indicated in the Materials and methods section. Animals were killed $10 \mathrm{~h}$ after hCG administration. (A) Ovarian mRNA expression of SOCS3 and $\beta$-actin as transcript control, by RT-PCR (upper panel) and quantitative analysis of mRNA bands (bottom panel). (B) Ovarian expression of SOCS3 protein and $\beta$-actin, as protein control, by western blot assay (upper panel) and quantitative analysis of immunoreactive bands (bottom panel). Results are expressed as the mean \pm s.E.M. for eight to ten samples per group. Each sample represents one ovary from each animal with the same treatment $(n=8-10) .{ }^{*} P<0.05$ vs controls (Student's $t$-test). 
A

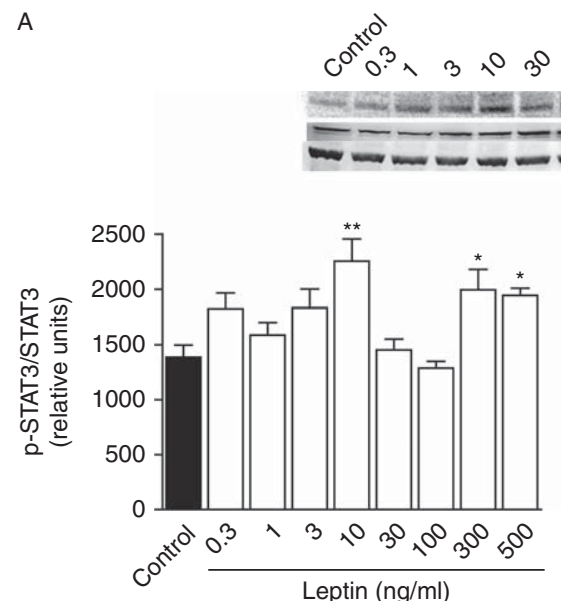

$$
\begin{aligned}
& \longleftarrow p-S T A T 3 \\
& \longleftarrow \text { STAT3 }
\end{aligned}
$$

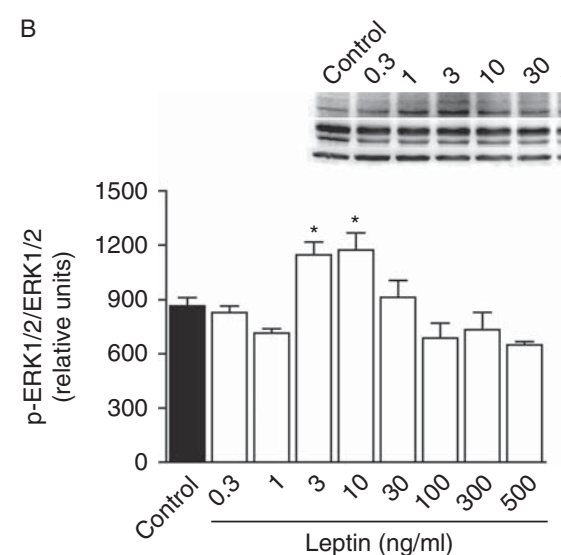

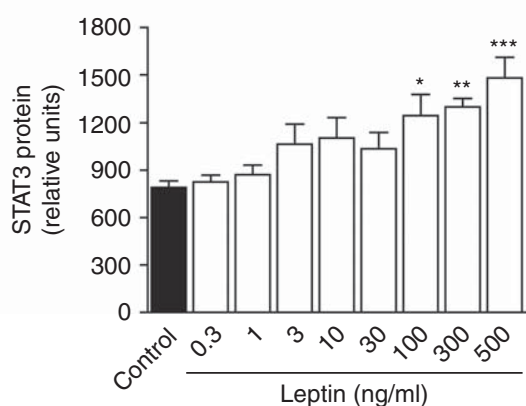

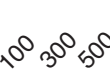

These increases represented $83 \%$ for the $100 \mathrm{ng} / \mathrm{ml}$ concentration $(P<0.01)$ and $39 \%$ for the $300 \mathrm{ng} / \mathrm{ml}$ concentration $(P<0.05)$.

Considering i) that the daily treatment with leptin induces (Roman et al. 2005) and the acute treatment reduces (Ricci et al. 2006) the levels of plasmatic progesterone, ii) that the presence of different levels of leptin causes a biphasic effect on progesterone secretion (Di Yorio et al. 2008) and iii) to link the changes found in the signalling pathways to a downstream biological event, we measured the secretion of progesterone in the ovarian incubation medium. Results are summarised in Table 2. The presence of leptin caused a dose-dependent biphasic effect on progesterone secretion, as described previously (Di Yorio et al. 2008). Progesterone concentration was significantly increased at $1-10 \mathrm{ng} / \mathrm{ml}$ and decreased at $300 \mathrm{ng} / \mathrm{ml}$. The addition of PD 98059, a specific inhibitor of the ERK $1 / 2$ pathway, completely suppressed both the increase and the decrease in the leptin-induced progesterone secretion by the ovarian tissue, whereas basal concentrations were not altered. The presence of AG 490, a specific inhibitor of the JAK2/STAT3 pathway, completely reversed the action of leptin on progesterone secretion at 1 and $300 \mathrm{ng} / \mathrm{ml}$ leptin $(P<0.01)$, but not at $3-10 \mathrm{ng} / \mathrm{ml}$ leptin $(P>0.05)$, although the levels of progesterone secretion were not significantly different from those of controls (Table 2).

\section{Discussion}

The acute treatment with leptin, which inhibits the ovulatory process, caused a decrease in the phosphorylation of ERK1/2 and an increase in the SOCS3 protein in the ovary. The finding that STAT3 phosphorylation decreased in parallel with an increase in total STAT3 protein in the ovary of rats that received the acute treatment suggests two possibilities: i) the STAT3 cascade is blocked by the increase in SOCS3 caused by the acute treatment with leptin and thus the constitutive protein increases to balance that inhibition or ii) STAT3 phosphorylation seems to be decreased by the increase in the total protein caused by leptin treatment. In either case, it was surprising that the phosphorylation of both STAT3 and ERK1/2 was blocked or reduced when compared with controls. In addition to leptin, other ovarian factors or interleukins, including hormones, can stimulate phosphorylation of these signalling proteins. Therefore, the phosphorylation detected in the control samples could be a leptin-independent activation and, in turn, leptin could be interfering in this activation. 
A
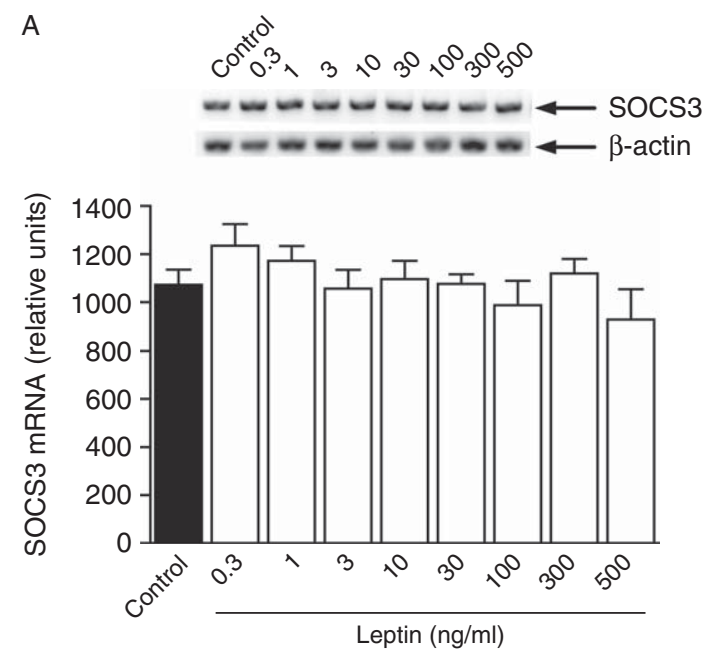

B
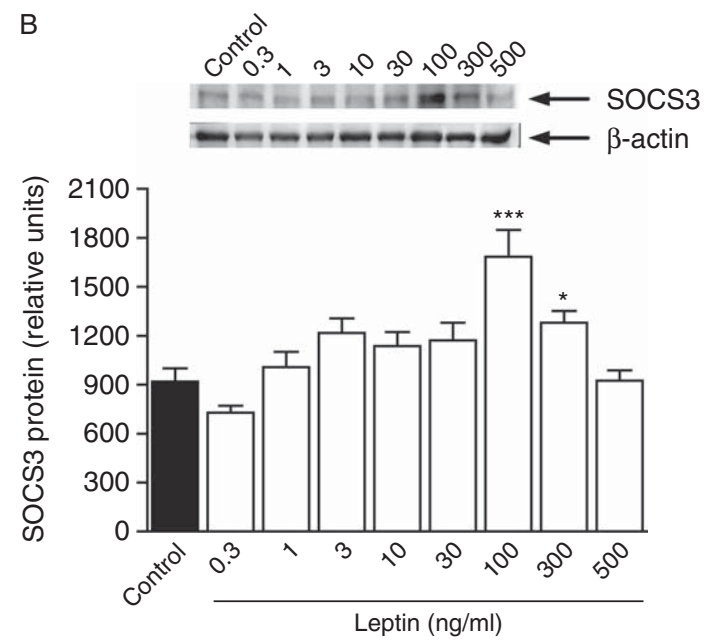

Figure 8 In vitro effect of leptin on the ovarian expression of both SOCS3 mRNA and protein. Ovarian explants were obtained $4 \mathrm{~h}$ after hCG administration from immature rats primed with eCG/hCG and incubated for $4 \mathrm{~h}$ either in the presence or in the absence (control) of different concentrations of leptin $(0.3-500 \mathrm{ng} / \mathrm{ml})$. (A) Ovarian mRNA expression of SOCS3 and $\beta$-actin as transcript control, by RT-PCR (upper panel) and quantitative analysis of mRNA bands (bottom panel). (B) Ovarian expression of SOCS3 protein and $\beta$-actin, as protein control, by western blot assay (upper panel) and quantitative analysis of protein bands (bottom panel). Results are expressed as the mean \pm s.E.M. of six independent experiments $(n=6) . * P<0.05$ and ${ }^{* * *} P<0.001$ vs controls (one-way ANOVA and Dunnett's multiple comparison test).

Another possibility is that the increased levels of SOCS3 caused by the acute treatment may induce leptin resistance at the ovarian level, as suggested in other studies with different systems. Münzberg et al. (2004) found that the arcuate nucleus, a specific region within the hypothalamus, is selectively leptin resistant in dietinduced obese mice and suggested that this may be caused by increased levels of SOCS3 in this hypothalamic nucleus. Li et al. (2007) suggested that the lower levels of p-STAT3 found in granulosa cells from women with polycystic ovarian syndrome, who exhibit hyperleptinaemia and high follicular fluid leptin, may be related to ovarian leptin resistance and fecundity in these women. Roy et al. (2007) found a clear leptin resistance when the OBRb/STAT3 signalling pathway was completely inhibited when $\mathrm{CHO}$ cells stably co-expressing $\mathrm{OBRb}$ were subjected to long-term prestimulation by leptin and that the overexposure to leptin induces the expression of the negative regulator SOCS3. Rodent and human obesity is characterised by hyperleptinaemia and by leptin resistance, the latter of which may be caused by a lack of or a decrease in intracellular signals. Based on multiple evidence, it has been suggested that the overreactivity of the SOCS pathway is a potential causal mechanism for leptin-resistant obesity (Bjørbæk 2009). Thus, in this study, it is possible that the acute treatment with leptin caused a leptin resistance state at the ovarian level.

The daily treatment with leptin, which induces the ovulatory process, led to a clear increased phosphorylation of both STAT3 and ERK1/2 and a decreased expression of SOCS3 protein. A significant body of evidence has demonstrated the involvement of either the JAK/STAT3 or MAPK signalling transduction pathway in different physiological events in the ovarian function, especially in the ovulatory process. The expression of interferon $\alpha$, a cytokine involved in the differentiation of rat preovulatory granulosa cells and in the expression of other ovulation-related genes, is induced by the presence of luteinising hormone (LH) in rat preovulatory granulosa cells via the ERK1/2 signalling pathway (Lee da et al. 2009). In porcine granulosa cells, IGF1 induction of cholesterol side-chain cleavage cytochrome (P450scc) expression is directly and specifically mediated through ERK phosphorylation (Denner et al. 2010). Recently, we observed a significant decrease in the ovarian expression of P450scc in parallel with that of ERK1/2 phosphorylation in the same samples of ovarian tissue from rats that received the acute treatment for the present work (Bilbao et al. 2013). This result is consistent with the finding that PD 98059, a specific inhibitor of ERK $1 / 2$ activation, was able to reverse the action of leptin on progesterone secretion in our in vitro studies. It is known that StAR protein (StAR) is involved in the acute regulation of steroidogenesis by facilitating the access of cholesterol to the P450scc action. Some authors have found that the activation of CAMP/protein kinase $\mathrm{A}$ (PKA) signalling by gonadotrophins not only induces steroidogenesis but also activates a down-regulation machinery that involves the ERK cascade. Indeed, activation of the ERK cascade downstream of PKA in turn regulates the level of StAR expression, which is probably the key participant in these down-regulation processes (Cameron et al. 1996, Seger et al. 2001). However, in a more recent study, it has been found that a PKA-dependent phosphorylation of ERK1/2, which in turn interacts with and phosphorylates StAR, is essential to induce steroid biosynthesis (Poderoso et al. 2008). 
Table 2 Progesterone secretion (ng/mg protein) by ovarian tissue from immature gonadotropin-primed rats in the presence of vehicle (control) and a combination of leptin $(0-300 \mathrm{ng} / \mathrm{ml})$ and/or specific inhibitors of kinases: PD $98059(50 \mu \mathrm{M})$ and AG $490(25 \mu \mathrm{M})(n=6-8)$.

\begin{tabular}{lccccc}
\hline & \multicolumn{5}{c}{ Leptin $(\mathrm{ng} / \mathrm{ml})$} \\
\cline { 2 - 5 } & 0 & 1 & 3 & 10 & 300 \\
\hline Control & $26 \pm 2$ & $50 \pm 5^{+}$ & $43 \pm 3^{\ddagger}$ & $45 \pm 3^{\ddagger}$ & $16 \pm 2^{*}$ \\
PD 98059 $(50 \mu \mathrm{M})$ & $26 \pm 3$ & $23 \pm 3^{\|}$ & $25 \pm 3^{\|}$ & $30 \pm 4^{\S}$ & $35 \pm 3^{\|}$ \\
AG 490 $(25 \mu \mathrm{M})$ & $31 \pm 3$ & $28 \pm 2^{\|}$ & $36 \pm 5$ & $39 \pm 4$ & $35 \pm 4^{\| \prime}$ \\
\hline
\end{tabular}

${ }^{*} P<0.05,{ }^{\dagger} P<0.01$ and ${ }^{\ddagger} P<0.001$ vs leptin $0 \mathrm{ng} / \mathrm{ml} .{ }^{\S} P<0.05$ and $" P<0.01$ vs the respective leptin concentration.

In addition, Fan et al. (2009) provided in vivo evidence that ERK1/2 is necessary for gonadotrophin-induced oocyte maturation, ovulation and luteinisation by mediating the expression of $\mathrm{FSH} / \mathrm{LH}$-target genes in ovarian cells. Taking all these data together and considering i) that the endogenous levels of leptin are drastically decreased (Ryan et al. 2003, Ricci et al. 2006) in parallel with an increase in plasma progesterone levels after hCG administration in gonadotrophinstimulated rats as used in the present and previous works (Ricci et al. 2006), which could indicate a possible role of leptin in the regulation of progesterone, ii) that the daily treatment with leptin induces and the acute treatment reduces the levels of progesterone (Roman et al. 2005, Ricci et al. 2006) and iii) that the presence of specific inhibitors of JAK/STAT and MAPK signalling pathways suppressed both the increase and the decrease in the leptin-induced progesterone secretion by the ovarian tissue, it is reasonable to suggest that leptin could be regulating steroidogenesis, at least in part, through both the ERK and STAT cascades, although an action on other signalling pathways cannot be ruled out.

It is generally accepted that SOCS3 is a negative regulator of cytokine signalling via the JAK/STAT pathway activated by the receptor-ligand complex. In this study, the ovarian expression of SOCS3 protein was increased by the acute treatment with leptin and decreased by the daily treatment. These changes occurred without concomitant alterations in SOCS3 mRNA. While no study has directly shown regulation of ovarian expression of SOCS3 by leptin during the ovulatory process, changes in SOCS3 expression have been observed in the ovary of rodents in response to prolactin-induced signalling during pregnancy and in lactating females (Curlewis et al. 2002, Anderson et al. 2009). In another study using $\mathrm{CHO}$ cells, it has been demonstrated that prolactin and leptin down-regulate their own signalling pathways through the same negative regulator, SOCS3, with no crosstalk between prolactin receptor and OBR (Roy et al. 2007). Therefore, to our knowledge, our results are the first to demonstrate that leptin is able to modulate the expression of SOCS3 in parallel with two different signalling cascades in the ovarian tissue during the ovulatory process in the rat, although we cannot state a direct relationship between SOCS3 and both signalling pathways in our biological models. While both treatments are not comparable, the different effects of leptin on these signalling proteins observed in this work may be in response to different levels of leptin and/or different timings of leptin administration. Therefore, further studies are necessary to clarify this point.

In our in vitro experiments, we also found that leptin was able to up-regulate the expression of both STAT3 and ERK1/2 at physiological concentrations and STAT3 at high concentrations $(300-500 \mathrm{ng} / \mathrm{ml})$. It is important to point out that the $3-10 \mathrm{ng} / \mathrm{ml}$ concentrations used in our in vitro studies are of the same order of magnitude as that found in circulation of normally fed rats and between 10 and $30 \mathrm{ng} / \mathrm{ml}$ in mildly obese rats (Watanobe \& Suda 1999, Almog et al. 2001). Thus, $300-500 \mathrm{ng} / \mathrm{ml}$ represents the pharmacological concentration of leptin in normally fed female rats, excluding pregnant rats, which are exposed to higher concentrations than nonpregnant ones (García et al. 2000). The different responses obtained with these signalling proteins when the gonads are directly exposed to leptin might be related to different action mechanisms. The pattern of responsiveness obtained with $\mathrm{p}$-STAT is i) similar to that observed by Ruiz-Cortés et al. (2003) in porcine granulosa cell cultures, where both low $(10 \mathrm{ng} / \mathrm{ml})$ and high $(1000 \mathrm{ng} / \mathrm{ml})$ leptin levels increase STAT3 phosphorylation and ii) consistent with that found in the expression of OBRb in a previous study using rats treated with gonadotrophins to induce the first ovulation as in the present work (Di Yorio et al. 2008). Thus, it is possible that, in the ovarian cells, the STAT3 phosphorylation caused by leptin is an OBRb-activated response. Unlike STAT3, the response profile observed with p-ERK in the present work is similar to that of progesterone measured in the culture medium of ovarian cells as 3-10 ng/ml leptin increases progesterone secretion (Ruiz-Cortés et al. 2003, Di Yorio et al. 2008) and StAR transcription (Ruiz-Cortés et al. 2003). Likewise, in our in vitro studies, the expression of SOCS3 was increased at high concentrations but not at low concentrations of leptin. Although it is difficult to compare an in vivo effect caused by a repeated or daily systemic exposure, as in our in vivo studies, with an effect caused by a tissue directly exposed to effective and known doses, this result seems to be similar to that obtained with the acute treatment and might indicate that high levels of leptin are 
able to up-regulate SOCS3 protein expression in ovarian tissue in parallel with a down-regulation of progesterone synthesis, as previously observed (Di Yorio et al. 2008). However, further studies are in progress to examine whether other signalling pathways are involved in the leptin action and to evaluate the relationship between these signalling proteins and the ovulatory process.

Although we cannot suggest which isoform mediates the activation of these signalling proteins, the action of leptin in our biological model may be the result of its binding to both receptor isoforms in a dose-dependent manner. Some authors have shown evidence that the short forms of leptin receptor appear to be the dominant forms expressed in different types of cells, including oocytes, and that these isoforms are capable of signalling through the MAPK pathway (Craig et al. 2004). Furthermore, it has been recently shown that OBRa is functional and plays a role in the regulation of steroidogenesis in human granulosa cells (Lin et al. 2009). However, our results support that the dual leptin action on steroidogenesis seems to be, at least in part, through both ERK and STAT cascades.

In conclusion, our results indicate that leptin is able to regulate STAT3, ERK1/2 and SOCS3 proteins at both intra- and extraovarian level. The leptin action on these signalling pathways could affect, at least in part, some other ovarian events, such as the synthesis of progesterone, which, in turn, could impact on the ovulatory rate as observed previously (Roman et al. 2005, Ricci et al. 2006).

\section{Declaration of interest}

The authors declare that there is no conflict of interest that could be perceived as prejudicing the impartiality of the research reported.

\section{Funding}

This work was supported by grant PIP 112-20080-00271 from Consejo Nacional de Investigaciones Científicas y Técnicas (CONICET) and UBACYT 20020100100280 from Universidad de Buenos Aires, Argentina.

\section{Acknowledgements}

The authors thank Dr Marcela Marquez and Enzo Cuba for their technical assistances in the maintenance and treatments of animals.

\section{References \\ Agarwal SK, Vogel K, Weitsman SR \& Magoffin DA 1999 Leptin antagonizes the insulin-like growth factor-1 augmentation of steroidogenesis in granulosa and theca cells of the human ovary. Journal of Clinical Endocrinology and Metabolism 84 1072-1076. (doi:10.1210/jc.84. 3.1072)}

Ahima RS, Dushay J, Flier SN, Prabakaran D \& Flier JS 1997 Leptin accelerates the onset of puberty in normal female mice. Journal of Clinical Investigation 99 391-395. (doi:10.1172/JCI119172)

Almog B, Gold R, Tajima K, Dantes A, Salim K, Rubinstein M, Barkan D, Homburg R, Lessing JB, Nevo N et al. 2001 Leptin attenuates follicular apoptosis and accelerates the onset of puberty in immature rats. Molecular and Cellular Endocrinology 183 179-191. (doi:10.1016/ S0303-7207(01)00543-3)

Anderson ST, Isa NN, Barclay JL, Waters MJ \& Curlewis JD 2009 Maximal expression of suppressors of cytokine signalling in the rat ovary occurs in late pregnancy. Reproduction 138 537-544. (doi:10.1530/REP-08-0425)

Arias-Álvarez M, García-García RM, Torres-Rovira L, González-Bulnes A, Rebollar PG \& Lorenzo PL 2010 Influence of leptin on in vitro maturation and steroidogenic secretion of cumulus-oocyte complexes through JAK2/STAT3 and MEK 1/2 pathways in the rabbit model. Reproduction 139 523-532. (doi:10.1530/REP-09-0309)

Banks AS, Davis SM, Bates SH \& Myers MG Jr 2000 Activation of downstream signals by the long form of the leptin receptor. Journal of Biological Chemistry 275 14563-14572. (doi:10.1074/jbc. 275.19.14563)

Barkan D, Jia H, Dantes A, Vardimon L, Amsterdam A \& Rubinstein M 1999 Leptin modulates the glucocorticoid-induced ovarian steroidogenesis. Endocrinology 140 1731-1738. (doi:10.1210/en.140.4.1731)

Barkan D, Hurgin V, Dekel N, Amsterdam A \& Rubinstein M 2005 Leptin induces ovulation in GnRH-deficient mice. FASEB Journal 19 133-135.

Baskin DG, Breininger JF \& Schwartz MW 2000 SOCS-3 expression in leptin-sensitive neurons of the hypothalamus of fed and fasted rats. Regulatory Peptides 92 9-15. (doi:10.1016/S0167-0115(00)00143-9)

Bilbao MG, Di Yorio MP \& Faletti AG 2013 Different levels of leptin regulate different target enzymes involved in progesterone synthesis. Fertility and Sterility 99 1460-1466. (doi:10.1016/j.fertnstert. 2012.12.014)

Bjørbæk C 2009 Central leptin receptor action and resistance in obesity. Journal of Investigative Medicine 57 789-794.

Bjørbæk C, Uotani S, da Silva B \& Flier JS 1997 Divergent signalling capacities of the long and short isoforms of the leptin receptor. Journal of Biological Chemistry 272 32686-32695. (doi:10.1074/jbc.272.51. 32686)

Bjørbæk C, Elmquist JK, Frantz JD, Shoelson SE \& Flier JS 1998 Identification of SOCS-3 as a potential mediator of central leptin resistance. Molecular Cell 1 619-625. (doi:10.1016/S10972765(00)80062-3)

Bjørbæk C, El-Haschimi K, Frantz JD \& Flier JS 1999 The role of SOCS-3 in leptin signalling and leptin resistance. Journal of Biological Chemistry 274 30059-30065. (doi:10.1074/jbc.274.42.30059)

Bjørbæk C, Lavery HJ, Bates SH, Olson RK, Davis SM, Flier JS \& Myers MG Jr 2000 SOCS3 mediates feedback inhibition of the leptin receptor via Tyr985. Journal of Biological Chemistry 275 40649-40657. (doi:10.1074/jbc.M007577200)

Bjørbæk C, Buchholz RM, Davis SM, Bates SH, Pierroz DD, Gu H, Neel BG, Myers MG Jr \& Flier JS 2001 Divergent roles of SHP-2 in ERK activation by leptin receptors. Journal of Biological Chemistry 276 4747-4755. (doi:10.1074/jbc.M007439200)

Cameron MR, Foster JS, Bukovsky A \& Wimalasena J 1996 Activation of mitogen-activated protein kinases by gonadotropins and cyclic adenosine $5^{\prime}$-monophosphates in porcine granulosa cells. Biology of Reproduction 55 111-119. (doi:10.1095/biolreprod55.1.111)

Caüzac M, Czuba D, Girard J \& Hauguel-de Mouzon S 2003 Transduction of leptin growth signals in placental cells is independent of JAK-STAT activation. Placenta 24 378-384. (doi:10.1053/plac.2002.0915)

Chehab FF, Lim ME \& Lu R 1996 Correction of the sterility defect in homozygous obese female mice by treatment with the human leptin. Nature Genetics 12 318-320. (doi:10.1038/ng0396-318)

Cioffi JA, Shafer AW, Zupancic TJ, Smith-Gbur J, Mikhah A, Platika D \& Snodgrass HR 1996 Novel B219/OB receptor isoforms: possible role of leptin in hematopoiesis and reproduction. Nature Medicine 2 585-589. (doi:10.1038/nm0596-585)

Cioffi JA, Van Blerkom J, Antczak M, Shafer A, Wittmer S \& Snodgrass HR 1997 The expression of leptin and its receptors in pre-ovulatory human follicles. Molecular Human Reproduction 3 467-472. (doi:10.1093/ molehr/3.6.467) 
Clément K, Vaisse C, Lahlou N, Cabrol S, Pelloux V, Cassuto D, Gourmelen M, Dina C, Chambaz J, Lacorte JM et al. 1998 A mutation in the human leptin receptor gene causes obesity and pituitary dysfunction. Nature 392 398-401. (doi:10.1038/32911)

Craig J, Zhu H, Dyce PW, Petrik J \& Li J 2004 Leptin enhances oocyte nuclear and cytoplasmic maturation via the mitogen-activated protein kinase pathway. Endocrinology 145 5355-5363. (doi:10.1210/en. 2004-0783)

Curlewis JD, Tam SP, Lau P, Kusters DH, Barclay JL, Anderson ST \& Waters MJ 2002 A prostaglandin $f(2 \alpha)$ analog induces suppressors of cytokine signalling-3 expression in the corpus luteum of the pregnant rat: a potential new mechanism in luteolysis. Endocrinology $\mathbf{1 4 3}$ 3984-3993. (doi:10.1210/en.2002-220344)

Denner L, Bodenburg YH, Jiang J, Pagès G \& Urban RJ 2010 Insulin-like growth factor-I activates extracellularly regulated kinase to regulate the p450 side-chain cleavage insulin-like response element in granulosa cells. Endocrinology 151 2819-2825. (doi:10.1210/en.2009-1439)

Di Yorio MP, Bilbao MG, Pustovrh MC, Prestifilippo JP \& Faletti AG 2008 Leptin modulates the expression of its receptors in the hypothalamicpituitary-ovarian axis in a differential way. Journal of Endocrinology 198 355-366. (doi:10.1677/JOE-07-0622)

Duggal PS, Van der Hoek KH, Milner CR, Ryan NK, Armstrong DT, Magoffin DA \& Norman RJ 2000 The in vivo and in vitro effects of exogenous leptin on ovulation in the rat. Endocrinology 141 1971-1976. (doi:10.1210/en.141.6.1971)

Duggal PS, Ryan NK, Van der Hoek KH, Ritter LJ, Armstrong DT, Magoffin DA \& Norman RJ 2002 Effects of leptin administration and feed restriction on thecal leukocytes in the preovulatory rat ovary and the effects of leptin on meiotic maturation, granulosa cell proliferation, steroid hormone and PGE2 release in cultured rat ovarian follicles. Reproduction 123 891-898. (doi:10.1530/rep.0.1230891)

Eguchi M, Gillis LC, Liu Y, Lyakhovsky N, Du M, McDermott JC \& Sweeney G 2007 Regulation of SOCS-3 expression by leptin and its co-localization with insulin receptor in rat skeletal muscle cells. Molecular and Cellular Endocrinology 267 38-45. (doi:10.1016/j.mce. 2006.11.009)

Fan HY, Liu Z, Shimada M, Sterneck E, Johnson PF, Hedrick SM \& Richards JS 2009 MAPK3/1(ERK1/2) in ovarian granulosa cells are essential for female fertility. Science 324 938-941. (doi:10.1126/science. 1171396)

García MD, Casanueva FF, Diéguez C \& Señarís RM 2000 Gestational profile of leptin messenger ribonucleic acid (mRNA) content in the placenta and adipose tissue in the rat, and regulation of the mRNA levels of the leptin receptor subtypes in the hypothalamus during pregnancy and lactation. Biology of Reproduction 62 698-703. (doi:10.1095/ biolreprod62.3.698)

Gruaz NM, Lalaoui M, Pierroz DD, Englaro P, Sizonenko PC, Blum WF \& Aubert ML 1998 Chronic administration of leptin into the lateral ventricle induces sexual maturation in severely food-restricted female rats. Journal of Neuroendocrinology 10 627-633. (doi:10.1046/j.13652826.1998.00247.x)

Karlsson C, Lindell K, Svensson E, Bergh C, Lind P, Billig H, Carlsson LM \& Carlsson B 1997 Expression of functional leptin receptors in the human ovary. Journal of Clinical Endocrinology and Metabolism 82 4144-4148. (doi:10.1210/jc.82.12.4144)

Kikuchi N, Andoh K, Abe Y, Yamada K, Mizunuma H \& Ibuki Y 2001 Inhibitory action of leptin on early follicular growth differs in immature and adult female mice. Biology of Reproduction 65 66-71. (doi:10.1095/ biolreprod65.1.66)

Kim YB, Uotani S, Pierroz DD, Flier JS \& Kahn BB 2000 In vivo administration of leptin activates signal transduction directly in insulinsensitive tissues: overlapping but distinct pathways from insulin. Endocrinology 141 2328-2339. (doi:10.1210/en.141.7.2328)

Laubner K, Kieffer TJ, Lam NT, Niu X, Jakob F \& Seufert J 2005 Inhibition of preproinsulin gene expression by leptin induction of suppressor of cytokine signalling 3 in pancreatic $\beta$-cells. Diabetes 54 3410-3417. (doi:10.2337/diabetes.54.12.3410)

Lee da L, Kim SH, Kim E, Chun SY \& Kim TS 2009 Interferon- $\alpha$ is involved in the luteinizing hormone-induced differentiation of rat preovulatory granulosa cells. Journal of Interferon \& Cytokine Research 29 801-808. (doi:10.1089/jir.2009.0024)
Li MG, Ding GL, Chen XJ, Lu XP, Dong LJ, Dong MY, Yang XF, Lu XE \& Huang HF 2007 Association of serum and follicular fluid leptin concentrations with granulosa cell phosphorylated signal transducer and activator of transcription 3 expression in fertile patients with polycystic ovarian syndrome. Journal of Clinical Endocrinology and Metabolism 92 4771-4776. (doi:10.1210/jc.2007-0978)

Lin Q, Poon SL, Chen J, Cheng L, HoYuen B \& Leung PC 2009 Leptin interferes with $3^{\prime}, 5^{\prime}$-cyclic adenosine monophosphate (cAMP) signalling to inhibit steroidogenesis in human granulosa cells. Reproductive Biology and Endocrinology 7 115-122. (doi:10.1186/ 1477-7827-7-115)

Matsuoka T, Tahara M, Yokoi T, Masumoto N, Takeda T, Yamaguchi M, Tasaka K, Kurachi H \& Murata Y 1999 Tyrosine phosphorylation of STAT3 by leptin through leptin receptor in mouse metaphase 2 stage oocyte. Biochemical and Biophysical Research Communications 256 480-484. (doi:10.1006/bbrc.1999.0365)

Mounzih K, Lu R \& Chehab FF 1997 Leptin treatment rescues the sterility of genetically obese ob/ob males. Endocrinology 138 1190-1193. (doi:10.1210/en.138.3.1190)

Münzberg H, Flier JS \& Bjørbæk C 2004 Region-specific leptin resistance within the hypothalamus of diet-induced obese mice. Endocrinology 145 4880-4889. (doi:10.1210/en.2004-0726)

Murakami T, Yamashita T, lida M, Kuwajima M \& Shima K 1997 A short form of leptin receptor performs signal transduction. Biochemical and Biophysical Research Communications 231 26-29. (doi:10.1006/ bbrc.1996.6030)

Nakamura S, Nishii N, Yamanaka A, Kitagawa H, Asano M, Tsubota T \& Suzuki M 2009 Leptin receptor (OBR) expression in the ovary and uterus of the wild japanese black bear (Ursus thibetanus japonicus). Journal of Reproduction and Development 55 110-115. (doi:10.1262/ jrd.20077)

Peiser C, McGregor GP \& Lang RE 2000 Leptin receptor expression and suppressor of cytokine signalling transcript levels in high-fat-fed rats. Life Sciences 67 2971-2981. (doi:10.1016/S0024-3205(00)00884-5)

Poderoso C, Converso DP, Maloberti P, Duarte A, Neuman I, Galli S, Maciel FC, Paz C, Carreras MC, Poderoso JJ et al. 2008 A mitochondrial kinase complex is essential to mediate an ERK1/2-dependent phosphorylation of a key regulatory protein in steroid biosynthesis. PLOS ONE 3 e1443. (doi:10.1371/journal.pone.0001443)

Ricci AG, Di Yorio MP \& Faletti AG 2006 Inhibitory effect of leptin on the rat ovary during the ovulatory process. Reproduction 132 771-780. (doi:10.1530/rep.1.01164)

Roman EA, Ricci AG \& Faletti AG 2005 Leptin enhances ovulation and attenuates the effects produced by food restriction. Molecular and Cellular Endocrinology 242 33-41. (doi:10.1016/j.mce.2005.07.007)

Roy AF, Benomar Y, Bailleux V, Vacher CM, Aubourg A, Gertler A, Djiane J \& Taouis M 2007 Lack of cross-desensitization between leptin and prolactin signalling pathways despite the induction of suppressor of cytokine signalling 3 and PTP-1B. Journal of Endocrinology 195 341-350. (doi:10.1677/JOE-07-0321)

Rozen S \& Skaletsky H 2000 Primer3 on the WWW for general users and for biologist programmers. Methods in Molecular Biology 132 365-386.

Ruiz-Cortés ZT, Martel-Kennes Y, Gévry NY, Downey BR, Palin MF \& Murphy BD 2003 Biphasic effects of leptin in porcine granulosa cells. Biology of Reproduction 68 789-796. (doi:10.1095/biolreprod.102. 010702)

Ryan NK, Van der Hoek KH, Robertson SA \& Norman RJ 2003 Leptin and leptin receptor expression in the rat ovary. Endocrinology $\mathbf{1 4 4}$ 5006-5013. (doi:10.1210/en.2003-0584)

Seger R, Hanoch T, Rosenberg R, Dantes A, Merz WE, Strauss JF III \& Amsterdam A 2001 The ERK signalling cascade inhibits gonadotropinstimulated steroidogenesis. Journal of Biological Chemistry 276 13957-13964. (doi:10.1074/jbc.M003766200)

Strobel A, Issad T, Camoin L, Ozata M \& Strosberg AD 1998 A leptin missense mutation associated with hypogonadism and morbid obesity. Nature Genetics 18 213-215. (doi:10.1038/ng0398-213)

Tartaglia LA, Dembski M, Weng X, Deng N, Culpepper J, Devos R, Richards GJ, Campfield LA, Clark FT, Deeds J et al. 1995 Identification and expression cloning of a leptin receptor, OBR. Cell 83 263-271. (doi:10.1016/0092-8674(95)90151-5) 
Watanobe H \& Suda T 1999 A detailed study on the role of sex steroid milieu in determining plasma leptin concentrations in adult male and female rats. Biochemical and Biophysical Research Communications 259 56-59. (doi:10.1006/bbrc.1999.0718)

Ye Y, Kawamura K, Sasaki M, Kawamura N, Groenen P, Sollewijn Gelpke MD, Kumagai J, Fukuda J \& Tanaka T 2009 Leptin and OBRa/MEK signalling in mouse oocyte maturation and preimplantation embryo development. Reproductive Biomedicine Online 19 181-190. (doi:10.1016/S1472-6483(10)60070-3)

Zachow RJ \& Magoffin DA 1997 Direct intraovarian effects of leptin: impairment of the synergistic action of insulin-like growth factor-I on follicle-stimulating hormone-dependent estradiol-17 $\beta$ production by rat ovarian granulosa cells. Endocrinology 138 847-850. (doi:10.1210/ en.138.2.847)
Zachow RJ, Weitsman SR \& Magoffin DA 1999 Leptin impairs the synergistic stimulation by transforming growth factor- $\beta$ of follicle-stimulating hormone-dependent aromatase activity and messenger ribonucleic acid expression in rat ovarian granulosa cells. Biology of Reproduction 61 1104-1109. (doi:10.1095/biolreprod61. 4.1104)

Received 15 June 2013

First decision 29 July 2013

Revised manuscript received 24 September 2013

Accepted 27 September 2013 